\title{
Characteristics and Mechanisms of Biosolubilization of Rock Phosphate by Aspergillus japonicus
}

\author{
Chunqiao Xiao ${ }^{1}$, Tingting Liu ${ }^{1}$, Guang $\mathrm{Xu}^{1}$, Ruan Chi ${ }^{1}$. \\ ${ }^{l}$ Wuhan Institute of Technology, Wuhan, China.
}

\begin{abstract}
Rock phosphate $(R P)$ is traditionally solubilized by chemical process causing high cost and environmental pollution. To reduce process cost and protect environment, RP solubilization by Aspergillus japonicus was studied and its mechanisms were discussed. Results show that A. japonicus could effectively solubilize RP in NBRIP medium. RP solubilization by A. japonicus included direct and indirect actions of the strain on RP. Cells of A. japonicus attached rapidly to RP surface and the RP surface was seriously corroded by the strain. A. japonicus excreted multiple organic acids, and followed by a significant increase of titratable acidity and decrease of $\mathrm{pH}$ in the culture. A positive correlation between content of soluble phosphate and quantity of titratable acidity but a negative correlation between content of soluble phosphate and $\mathrm{pH}$ were observed. Results of abiotic solubilization of RP using organic and inorganic acids indicated that the release of soluble phosphate was significantly lower than that of inoculated with A. japonicus. Higher release of soluble phosphate and $\mathrm{pH}$ reduction achieved when using ammonium nitrogen rather than nitrate nitrogen.
\end{abstract}

Key words: Biosolubilization; Soluble phosphate; Rock phosphate (RP); Aspergillus japonicus

*Author for correspondence: whjhx@aliyun.com 


\section{INSTRODUCTION}

Phosphorus is an essential macronutrient for plants and is added to soil in the form of phosphate fertilizers ${ }^{1}$. Natural rock phosphate (RP) has been recognized as a valuable alternative for phosphate fertilizer ${ }^{2}$. With the current tendency for a reduced use of agrochemicals and efficient application of natural materials in agroecosystems, a renewed interest in direct application of RP has arisen ${ }^{3}$. However, most natural RP found in the world is classified as low reactive and, therefore, its direct application is not always effective without previous treatment.

Microorganisms are involved in a range of processes that affect the transformation of soil phosphorus and are thus an integral part of the soil phosphorus cycle ${ }^{4}$. Some studies had shown microorganisms could solubilize insoluble RP and convert insoluble phosphate into soluble form ${ }^{5-7}$. There have many different observations about the mechanisms for phosphate solubilization by microorganisms, and they should be studied in depth since there is current interest in the use of microorganisms capable of solubilizing inorganic phosphates. Unfortunately, the reported mechanisms for phosphate solubilization did not hold true for all studies. Actually, there have even some opposite results on the mechanisms for the biosolubilization of RP today. Therefore, it is necessary to study the characteristics and mechanisms for the biosolubilization of RP under different conditions, such as different microorganisms, different culture medium, and so on.

Members of genus Aspergillus were traditionally recognized as potential soil inoculants and reports on RP solubilization had been made, such as Aspergillus aculeatus, Aspergillus tubingensis and Aspergillus niger etc ${ }^{8,9}$. However, few studies were reported on RP solubilization by Aspergillus japonicus (A. japonicus). In the present study, the solubilizing characteristics of RP by A. japonicus were studied. The mechanisms for RP solubilization by this fungus were also discussed.

\section{MATERIAL AND METHODS}

\section{Strain and RP Sample}

The strain used in this study was isolated from Yichang phosphate mines (Hubei, China). It was identified as Aspergillus japonicus (A. japonicus) on the basis of morphological, physiological and biochemical characterization and by sequencing of 18S rRNA gene (data not shown). The RP sample used in this experiment was obtained from Yichang phosphate mines (Hubei, P. R. China). The main chemical compositions of the sample are $8.35 \% \mathrm{P}, 24.78 \% \mathrm{Ca}, 9.85 \% \mathrm{Si}, 9.66 \% \mathrm{Mg}, 1.24 \%$ $\mathrm{Na}, 0.93 \% \mathrm{Al}$, and $0.56 \% \mathrm{Fe}$, respectively. The sample was ground to a particle size of almost 100-200 mesh. X-ray diffraction (XRD) analysis showed that the sample was mainly composed of hydroxyapatite and a small quantity of quartz and montmorillonite. The RP sample was sterilized by autoclaving at $121^{\circ} \mathrm{C}$ for $20 \mathrm{~min}$ before used.

\section{Culture medium and solubilizing conditions}

A. japonicus was cultured at $30^{\circ} \mathrm{C}$ on National Botanical Research Institute's phosphate growth (NBRIP) agar ${ }^{10}$ [glucose, $10 \mathrm{~g}$; $\left(\mathrm{NH}_{4}\right)_{2} \mathrm{SO}_{4}, 0.15 \mathrm{~g} ; \mathrm{KCl}, 0.2 \mathrm{~g}$; $\mathrm{MgCl}_{2} .6 \mathrm{H}_{2} 0,0.5 \mathrm{~g} ; \mathrm{MgSO}_{4} .7 \mathrm{H}_{2} \mathrm{O}, 0.25 \mathrm{~g}$; agar, $20 \mathrm{~g}$; distilled water, $\left.1000 \mathrm{~mL}\right]$ containing $5 \mathrm{~g}$ tricalcium phosphate $\left[\mathrm{TCP}, \mathrm{Ca}_{3}\left(\mathrm{PO}_{4}\right)_{2}\right]$ as sole phosphorus source. After culture for 3 days, spores of A. japonicus was scratched from NBRIP agar and added to sterile water. Spores suspensions of A. japonicus were counted by a haemocytometer to adjust the count to approximately $10^{7}$ cells $/ \mathrm{ml}$. Solubilizing experiments were carried out in flasks with $50 \mathrm{~mL}$ NBRIP medium (without agar) 
and $0.1 \mathrm{~g}$ sterilized RP sample as sole phosphorus source. Each flask was inoculated with the spore suspension at $10 \%(\mathrm{~V} / \mathrm{V})$. Flasks were shaken under $140 \mathrm{rpm}$ at $30^{\circ} \mathrm{C}$ for 7 days. The initial $\mathrm{pH}$ in the culture was adjusted at 7 by adding sterile $2 \% \mathrm{H}_{2} \mathrm{SO}_{4}$ or $\mathrm{NaOH}$ solution. A $5 \mathrm{ml}$ culture was daily removed from each flask for 7 days, and then assessed for population of the strain, titratable acidity, $\mathrm{pH}$, and organic acids. Solid residue was fixed in $2.5 \%$ glutaraldehyde, washed, dried and finally examined by Scanning Electron Microscope (SEM, JSM-5510LV, JEOL, Japan). All experiments were performed in triplicate.

\section{Abiotic solubilization of RP by organic and inorganic acids}

To study the effect of organic acids on RP solubilization, same concentration as detected in the medium inoculated with A. japonicus of gluconic acid and acetic acid were added to the medium. To study the effect of organic acids on RP solubilization, $0.1 \mathrm{M} \mathrm{HCl}$ and $\mathrm{H}_{3} \mathrm{PO}_{4}$ were added until the $\mathrm{pH}$ was as close as possible to that of the medium inoculated with $A$. japonicus. Each flask was inoculated and incubated at room temperature for $2 \mathrm{~h}$ prior to subsampling. The solution was centrifuged and assessed for the content of soluble phosphate and $\mathrm{pH}$.

\section{Effect of nitrogen sources on RP solubilization by $A$. japonicus}

The effect of nitrogen sources on RP solubilization by A. japonicus was evaluated by replacement of ammonium sulfate with five nitrogen sources, viz. ammonium chloride, ammonium nitrate, potassium nitrate, sodium nitrate, and calcium nitrate, respectively.

\section{Analysis Methods}

The content of soluble phosphate was determined by using phosphomolybdate method with a UV-VIS 8500 spectrophotometer at $490 \mathrm{~nm}^{11}$. For attachment experiments, the number of planktonic cells was determined by direct counting using a haemocytometer. The amount of attached cells was calculated by subtracting the remaining planktonic cells from the initial cells amount. The $\mathrm{pH}$ in the culture was recorded with a $\mathrm{pH}$ meter equipped with glass electrode. The titratable acidity was determined by standard $\mathrm{NaOH}$ solutions ${ }^{12}$. Organic acids were detected by High Performance Liquid Chromatography (HPLC, Agilent 1100, USA) at $214 \mathrm{~nm}^{13}$. Organic acids standards included citric, oxalic, gluconic, formic, $\alpha$-ketoglutaric, fumaric, lactic, pyruvic, succinic, tartaric, and ascorbic acids. Activities of acid and alkaline phosphatases were determined using a modification of the method of Tahatabai and Bremmer ${ }^{14}$. One milliliter filtrate was blended with $1 \mathrm{~mL}$ of 25 $\mathrm{mmol} / \mathrm{L} \rho$-nitrophenyl phosphate $(\rho \mathrm{NPP})$ and $4 \mathrm{~mL}$ modified universal buffer $(\mathrm{pH}$ 6.5 or $\mathrm{pH} 11$ for the assay of acid or alkaline phosphatases, respectively) at $37^{\circ} \mathrm{C}$ in the dark. The reaction was terminated after $1 \mathrm{~h}$ by adding $1 \mathrm{~mL}$ of $0.5 \mathrm{~mol} / \mathrm{L} \mathrm{CaCl}_{2}$ and $4 \mathrm{~mL}$ of $0.5 \mathrm{~mol} / \mathrm{L} \mathrm{NaOH}$. The mixtures were filtered, and the filtrate was measured at $410 \mathrm{~nm}$. Values were given as mean \pm standard deviation for triplicate samples.

\section{RESULTS}

\section{Attachment of A. japonicus on RP surface}

The attachment of A. japonicus on RP surface was displayed in Fig. 1. Result showed that cells of the strain attached rapidly on the RP surface, and the maximum amount up to $90 \%$ of cells attached to RP surface was reached at the second day. However, there was no obvious increase but a slight decrease in the percent of 
attached cells after $2 \mathrm{~d}$. SEM observations revealed the morphological features of RP surface solubilized by A. japonicus after $7 \mathrm{~d}$. As showed in the typical images, compared with the control sample (shown in Fig. 2a), A. japonicus attached on the RP surface selectively, and formed many slots and pits on the RP surface (Fig. 2b).

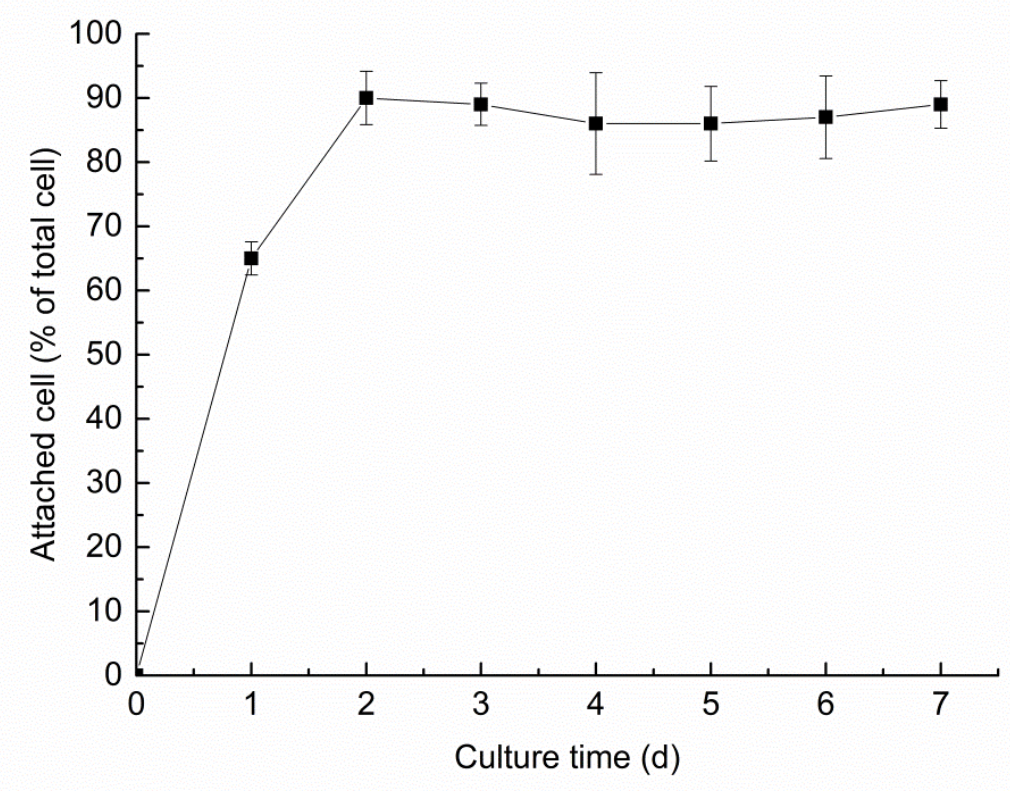

Figure 1 - Attachment of cells of A. japonicus on RP surface in culture during 7 days experiment. Results represent the mean of three replicates \pm standard deviation.
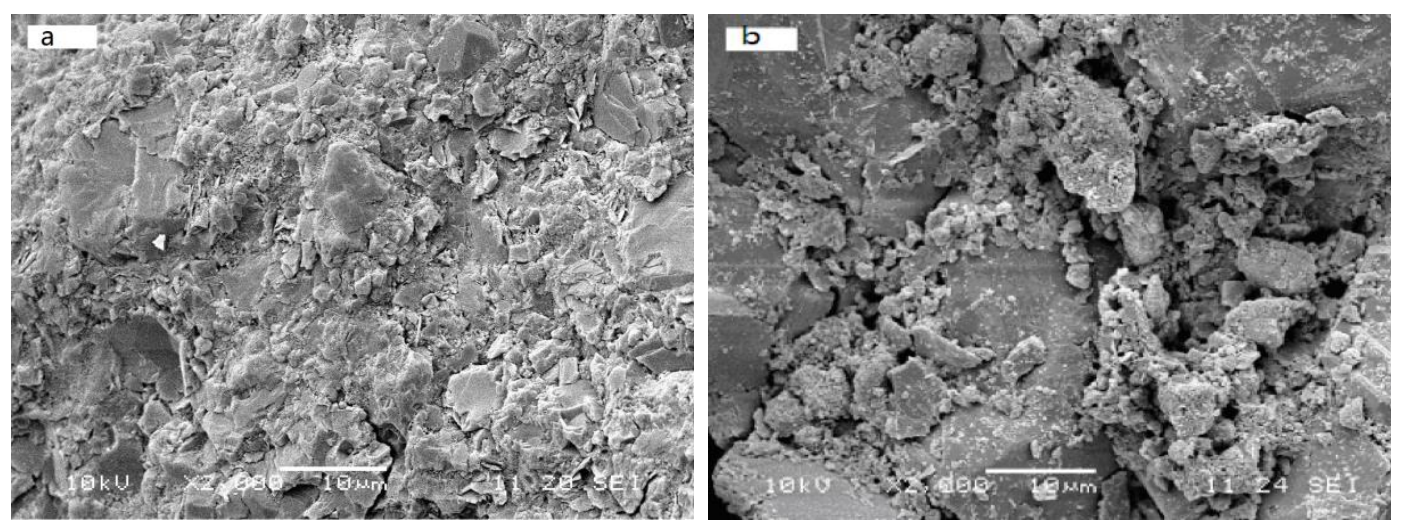

Figure 2 - Scanning electron micrographs of RP surface after 7 days experiment (a. Control; b. RP surface solubilized by A. japonicus).

\section{Soluble phosphate released from RP by $A$. japonicus}

The content of soluble phosphate in the culture during 7 days of experiment was investigated and the result presented in Fig. 3. The content of soluble phosphate in the culture increased significantly from the first day to the seventh day. This indicated that the fungus $A$. japonicus could effectively release soluble phosphate from insoluble RP. The $\mathrm{pH}$ dropped sharply after inoculation, and it decreased to 3.94 at the fifth day, which was the lowest value during the experiment. After the fifth day, the $\mathrm{pH}$ remained almost constant up to the seventh day. The titratable acidity was also detected, and the result showed that it increased significantly during 7 days of experiment. 


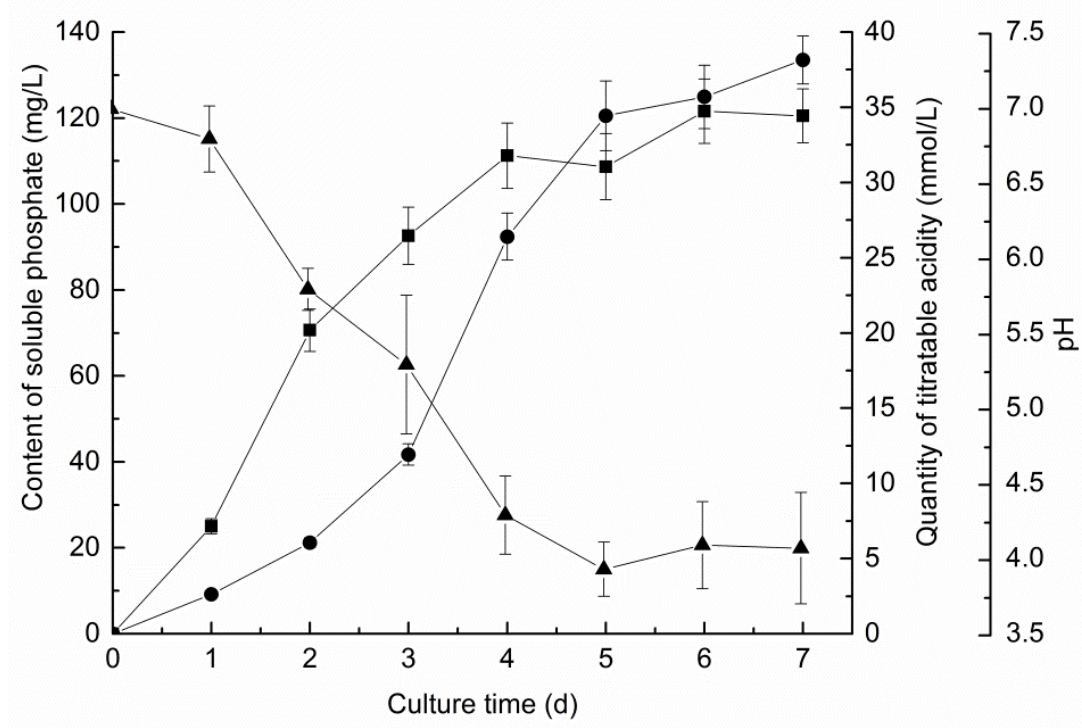

Figure 3- Changes in content of soluble phosphate $(\bullet), \mathrm{pH}(\boldsymbol{\Delta})$ and quantity of titratable acidity ( $\boldsymbol{\bullet})$ in culture during 7 days experiment. Results represent the mean of three replicates \pm standard deviation.

\section{Detection of organic acids in culture}

The phosphate solubilizing activity of microorganisms may be determined by the microbial metabolism to excrete organic acids ${ }^{15-17}$. These organic acids were known for their chelating ability, allowing them to combine with metal ions, such as $\mathrm{Ca}^{2+}$, and thus facilitated phosphate solubilization ${ }^{18}$. In the present study, organic acids in the culture were detected by HPLC analysis (Table 1). Results showed that almost all the organic acids standards were detected in the culture and their concentration varied during the experiment. The organic acids excreted by A. japonicus played a vital role in the acidification of the broth, which could be illustrated by the decrease of $\mathrm{pH}$ and increase of titratable acidity, and thus further facilitated the solubilization of RP. Results also show that gluconic acid was predominantly produced by the fungus among all the organic acids detected in this study.

Table 1- Organic acids detected and their concentration $(\mathrm{mg} / \mathrm{L})$ in culture inoculated with A. japonicus during 7 days experiment. Results represent the mean of three replicates \pm standard deviation.

\begin{tabular}{|c|c|c|c|c|c|c|c|}
\hline & $\mathrm{d} 1$ & $\mathrm{~d} 2$ & $\mathrm{~d} 3$ & $\mathrm{~d} 4$ & $\mathrm{~d} 5$ & d6 & $\mathrm{d} 7$ \\
\hline Citric acid & $0.56 \pm 0.08$ & $2.74 \pm 0.21$ & $5.19 \pm 0.26$ & $8.14 \pm 0.72$ & $8.35 \pm 0.44$ & $10.27 \pm 0.70$ & $11.73 \pm 0.81$ \\
\hline Oxalic acid & $18.95 \pm 1.36$ & $40.27 \pm 2.66$ & $39.28 \pm 3.05$ & $42.0 \pm 2.84$ & $36.87 \pm 2.20$ & $39.14 \pm 1.99$ & $35.15 \pm 2.47$ \\
\hline $\begin{array}{l}\text { Gluconic } \\
\text { acid }\end{array}$ & $56.84 \pm 3.68$ & $184.67 \pm 15.24$ & $195.37 \pm 10.77$ & $157.58 \pm 13.41$ & $129.47 \pm 6.94$ & $130.44 \pm 9.71$ & $133.69 \pm 10.41$ \\
\hline $\begin{array}{l}\text { Formic } \\
\text { acid }\end{array}$ & $-{ }^{*}$ & trace & $8.54 \pm 1.01$ & $10.16 \pm 0.77$ & $13.72 \pm 0.96$ & $10.28 \pm 0.75$ & $10.79 \pm 1.26$ \\
\hline $\begin{array}{l}\alpha- \\
\text { ketoglutaric } \\
\text { acid }\end{array}$ & trace & $3.94 \pm 0.12$ & $5.26 \pm 0.40$ & $5.57 \pm 0.74$ & $9.91 \pm 0.43$ & $16.15 \pm 0.99$ & $19.70 \pm 1.55$ \\
\hline $\begin{array}{l}\text { Fumaric } \\
\text { acid }\end{array}$ & $2.71 \pm 0.12$ & $3.24 \pm 0.16$ & $6.47 \pm 0.26$ & $9.59 \pm 0.48$ & $14.35 \pm 1.20$ & $9.08 \pm 0.59$ & $12.93 \pm 0.74$ \\
\hline Lactic acid & - & trace & trace & $3.25 \pm 0.09$ & $5.76 \pm 0.38$ & $7.47 \pm 0.63$ & $6.24 \pm 0.95$ \\
\hline $\begin{array}{l}\text { Pyruvic } \\
\text { acid }\end{array}$ & trace & trace & trace & $2.08 \pm 0.11$ & $3.84 \pm 0.18$ & $4.25 \pm 0.22$ & $3.29 \pm 0.13$ \\
\hline Succinic & trace & $3.49 \pm 0.13$ & $6.89 \pm 0.40$ & $8.02 \pm 0.55$ & $12.47 \pm 1.29$ & $16.88 \pm 1.34$ & $17.21 \pm 0.92$ \\
\hline
\end{tabular}


acid

Tartaric

$2.18 \pm 0.15 \quad 3.55 \pm 0.20$

$4.34 \pm 0.18$

$10.34 \pm 0.85$

$11.16 \pm 1.02$

$13.49 \pm 1.06$

$13.45 \pm 1.0$

acid

Ascorbic

trace

trace

trace

$1.02 \pm 0.10$

$3.75 \pm 0.23$

* Not detected.

\section{Mechanisms of RP solubilization by A. japonicus}

Generally, the mechanisms of microbial solubilization of minerals were recognized as direct and indirect actions ${ }^{19}$. In this study, Fig. 1 and Fig. 2 showed that cells of $A$. japonicus attached rapidly to RP surface and the RP surface could be seriously corroded by the strain. It indicated that the direct action by A. japonicus was one of the mechanisms for RP solubilization.

The results showed in Table 1 indicated that the indirect action by A. japonicus was another reason for RP solubilization. During the solubilizing process, A. japonicus excreted multiple organic acids in the culture. The acidification of the culture by the production of organic acids facilitated the release of soluble phosphate was another mechanism of RP solubilization by A. japonicus. This could be illustrated by the statistical analysis of correlation between soluble phosphate content, quantity of titratable acidity, and $\mathrm{pH}$. The increase of soluble phosphate content in the culture was accompanied by a significant rise of quantity of titratable acidity and drop of $\mathrm{pH}$. A significant positive correlation $(\mathrm{r}=0.76 ; \mathrm{p}<0.01)$ between soluble phosphate content and quantity of titratable acidity and a strong negative correlation $(\mathrm{r}=-0.91$; $\mathrm{p}<0.01$ ) between soluble phosphate content and $\mathrm{pH}$ were observed (Fig. 4).

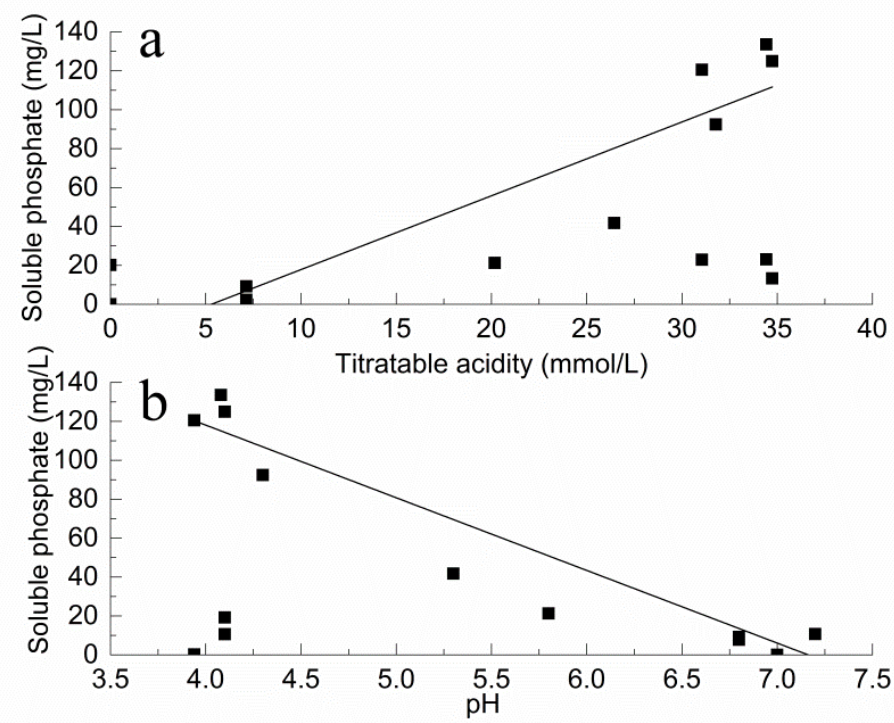

Figure 4- Linearity relationships between soluble phosphate content and quantity of titratable acidity (a), and soluble phosphate content and $\mathrm{pH}$ (b) in culture.

\section{Abiotic solubilization of RP by organic and inorganic acids}

Organic acids, especially gluconic acid played a vital role in the RP solubilization by A. japonicus in this study. The result prompted us to investigate the differences of RP solubilization by organic and inorganic acids. In the present study, the importance of organic acids in the RP solubilization was assessed by adding gluconic acid and acetic acid to the medium without inoculation of A. japonicus, at a concentration similar to the level of gluconic acid detected in the medium inoculated with the fungus. However, this strategy failed to affect the release of soluble 
phosphate to the comparable levels with inoculation of A. japonicus in the medium. As shown in Table 2, it was obvious that the organic acid released less soluble phosphate than that of by A. japonicus.

Likewise, the effect of inorganic acids $\left(\mathrm{HCl}\right.$ or $\left.\mathrm{H}_{3} \mathrm{PO}_{4}\right)$ on the RP solubilization under sterile condition was also studied. When the $\mathrm{pH}$ of the medium was finally adjusted to different $\mathrm{pH}$ values similar to the level detected in the medium inoculated with A. japonicus, only a small amount of soluble phosphate was released, which was significantly smaller than the values detected in the medium incubated with $A$. japonicus (Table 2). Our results further demonstrated multiple actions in addition to mere presence of organic or inorganic acids acid account for the microbial solubilization of $\mathrm{RP}^{20}$.

Table 2- Comparison of RP solubilization by A. japonicus and abiotic solubilization of RP by organic and inorganic acids. Results represent the mean of three replicates \pm standard deviation.

\begin{tabular}{|c|c|c|c|c|c|c|c|c|c|c|c|}
\hline \multirow{2}{*}{$\begin{array}{l}D \\
a \\
y\end{array}$} & \multicolumn{3}{|c|}{ A. japonicus } & \multicolumn{2}{|c|}{ Gluconic acid } & \multicolumn{2}{|c|}{ Acetic acid } & \multicolumn{2}{|c|}{$\mathrm{HCl}$} & \multicolumn{2}{|c|}{$\mathrm{H}_{3} \mathrm{PO}_{4}$} \\
\hline & $\begin{array}{l}\text { Conce } \\
\text { ntratio } \\
\mathrm{n} \quad \text { of } \\
\text { gluco } \\
\text { nic } \\
\text { acid } \\
\text { detect } \\
\text { ed } \\
(\mathrm{mg} / \mathrm{L} \\
)\end{array}$ & $\begin{array}{l}\mathrm{p} \\
\mathrm{H}\end{array}$ & $\begin{array}{l}\text { Sol } \\
\text { uble } \\
\text { pho } \\
\text { sph } \\
\text { ate } \\
\text { rele } \\
\text { ased } \\
\text { (mg } \\
\text { /L) }\end{array}$ & $\begin{array}{l}\text { Conc } \\
\text { entrat } \\
\text { ion } \\
(\mathrm{mg} / \\
\mathrm{L})\end{array}$ & $\begin{array}{l}\text { Sol } \\
\text { uble } \\
\text { pho } \\
\text { sph } \\
\text { ate } \\
\text { rele } \\
\text { ased } \\
\text { (mg } \\
\text { /L) }\end{array}$ & $\begin{array}{l}\text { Conc } \\
\text { entrat } \\
\text { ion } \\
(\mathrm{mg} / \\
\mathrm{L})\end{array}$ & $\begin{array}{l}\text { Sol } \\
\text { uble } \\
\text { pho } \\
\text { sph } \\
\text { ate } \\
\text { rele } \\
\text { ased } \\
\text { (mg } \\
\text { /L) }\end{array}$ & $\begin{array}{l}\mathrm{p} \\
\mathrm{H}\end{array}$ & $\begin{array}{l}\text { Sol } \\
\text { uble } \\
\text { pho } \\
\text { sph } \\
\text { ate } \\
\text { rele } \\
\text { ased } \\
\text { (mg } \\
\text { /L) }\end{array}$ & $\begin{array}{l}\mathrm{p} \\
\mathrm{H}\end{array}$ & $\begin{array}{l}\text { Sol } \\
\text { uble } \\
\text { pho } \\
\text { sph } \\
\text { ate } \\
\text { rele } \\
\text { ased } \\
\text { (mg } \\
\text { /L) }\end{array}$ \\
\hline 1 & $\begin{array}{l}50.2 \pm \\
2.5\end{array}$ & $\begin{array}{l}6 . \\
8 \\
\pm \\
0 . \\
3\end{array}$ & $\begin{array}{l}9.7 \pm \\
1.5\end{array}$ & 50.2 & $\begin{array}{l}8.2 \pm \\
0.4\end{array}$ & 50.2 & $\begin{array}{l}4.5 \pm \\
0.6\end{array}$ & $\begin{array}{l}6 \\
8 \\
8\end{array}$ & $\begin{array}{l}0.8 \pm \\
0.3\end{array}$ & $\begin{array}{l}6 \\
8 \\
8\end{array}$ & $\begin{array}{l}0.4 \pm \\
0.2\end{array}$ \\
\hline 2 & $\begin{array}{l}179.3 \\
\pm 5.7\end{array}$ & $\begin{array}{l}5 . \\
7 \\
\pm \\
0 . \\
4\end{array}$ & $\begin{array}{l}24.3 \\
\pm 2.8\end{array}$ & 179.3 & $\begin{array}{l}21.5 \\
\pm 3.4\end{array}$ & 179.3 & $\begin{array}{l}13.4 \\
\pm 1.2\end{array}$ & $\begin{array}{l}5 \\
7\end{array}$ & $\begin{array}{l}9.4 \pm \\
0.5\end{array}$ & $\begin{array}{l}5 \\
7 \\
7\end{array}$ & $\begin{array}{l}3.3 \pm \\
0.3\end{array}$ \\
\hline 3 & $\begin{array}{l}201.6 \\
\pm 9.3\end{array}$ & $\begin{array}{l}5 . \\
2 \\
\pm \\
0 . \\
3\end{array}$ & $\begin{array}{l}42.8 \\
\pm 3.6\end{array}$ & 201.6 & $\begin{array}{l}30.3 \\
\pm 3.7\end{array}$ & 201.6 & $\begin{array}{l}15.7 \\
\pm 0.9\end{array}$ & $\begin{array}{l}5 \\
2 \\
2\end{array}$ & $\begin{array}{l}10.2 \\
\pm 0.9\end{array}$ & $\begin{array}{l}5 \\
2\end{array}$ & $\begin{array}{l}4.1 \pm \\
0.3\end{array}$ \\
\hline 4 & $\begin{array}{l}171.2 \\
\pm 8.2\end{array}$ & $\begin{array}{l}4 . \\
5 \\
\pm \\
0 . \\
3\end{array}$ & $\begin{array}{l}93.1 \\
\pm 7.5\end{array}$ & 171.2 & $\begin{array}{l}20.7 \\
\pm 4.1\end{array}$ & 171.2 & $\begin{array}{l}13.1 \\
\pm 0.6\end{array}$ & $\begin{array}{l}4 \\
5\end{array}$ & $\begin{array}{l}11.9 \\
\pm 1.3\end{array}$ & $\begin{array}{l}4 \\
5\end{array}$ & $\begin{array}{l}4.7 \pm \\
0.5\end{array}$ \\
\hline 5 & $\begin{array}{l}137.6 \\
\pm 9.4\end{array}$ & $\begin{array}{l}3 . \\
9 \\
\pm \\
0 . \\
2\end{array}$ & $\begin{array}{l}124 \\
9 \pm 1 \\
7.3\end{array}$ & 137.6 & $\begin{array}{l}19.4 \\
\pm 2.8\end{array}$ & 137.6 & $\begin{array}{l}9.7 \pm \\
0.4\end{array}$ & $\begin{array}{l}3 \\
9 \\
9\end{array}$ & $\begin{array}{l}25.7 \\
\pm 1.2\end{array}$ & $\begin{array}{l}3 \\
9 \\
9\end{array}$ & $\begin{array}{l}6.4 \pm \\
1.0\end{array}$ \\
\hline 6 & $\begin{array}{l}135.5 \\
\pm 7.9\end{array}$ & $\begin{array}{l}4 . \\
0 \\
\pm\end{array}$ & $\begin{array}{l}128 \\
7 \pm 1 \\
0.2\end{array}$ & 135.5 & $\begin{array}{l}18.8 \\
\pm 2.2\end{array}$ & 135.5 & $\begin{array}{l}9.0 \pm \\
0.7\end{array}$ & $\begin{array}{l}4 \\
0 \\
0\end{array}$ & $\begin{array}{l}23.4 \\
\pm 0.6\end{array}$ & $\begin{array}{l}4 \\
0 \\
0\end{array}$ & $\begin{array}{l}5.2 \pm \\
0.6\end{array}$ \\
\hline
\end{tabular}




\begin{tabular}{|c|c|c|c|c|c|c|c|c|c|c|c|}
\hline \multirow{3}{*}{7} & & $\begin{array}{l}0 . \\
1\end{array}$ & & & & & & & & & \\
\hline & $\begin{array}{l}141.0 \\
\pm 8.1\end{array}$ & $\begin{array}{l}4 . \\
1\end{array}$ & $\begin{array}{l}135 \\
2 \pm 1\end{array}$ & 141.0 & $\begin{array}{r}20.3 \\
\pm 3.5\end{array}$ & 141.0 & $\begin{array}{l}9.8 \pm \\
0.5\end{array}$ & & $\begin{array}{l}23.1 \\
\pm 1.7\end{array}$ & $\begin{array}{l}4 \\
.\end{array}$ & $\begin{array}{l}3.9 \pm \\
0.8\end{array}$ \\
\hline & & $\begin{array}{l} \pm \\
0 . \\
2\end{array}$ & 9.7 & & & & & 1 & & 1 & \\
\hline
\end{tabular}

Comparison of ammonium and nitrate nitrogen sources on RP solubilization by A. japonicus

It was reported that a probable reason, except for organic acids production, was the release of protons accompanying respiration or $\mathrm{NH}_{4}{ }^{+}$assimilation ${ }^{21}$. In this study, different ammonium and nitrate nitrogen sources were used to investigate the effect of $\mathrm{NH}_{4}{ }^{+}$on RP solubilization by A. japonicus, respectively. Better release of soluble phosphate and $\mathrm{pH}$ reduction were observed when $\mathrm{NH}_{4}{ }^{+}$rather than $\mathrm{NO}_{3}{ }^{-}$was used as the nitrogen source (Fig. 5). The results further confirmed that $\mathrm{H}^{+}$extrusion by $\mathrm{NH}_{4}{ }^{+}$ assimilation may also be involved in the phosphate solubilization.

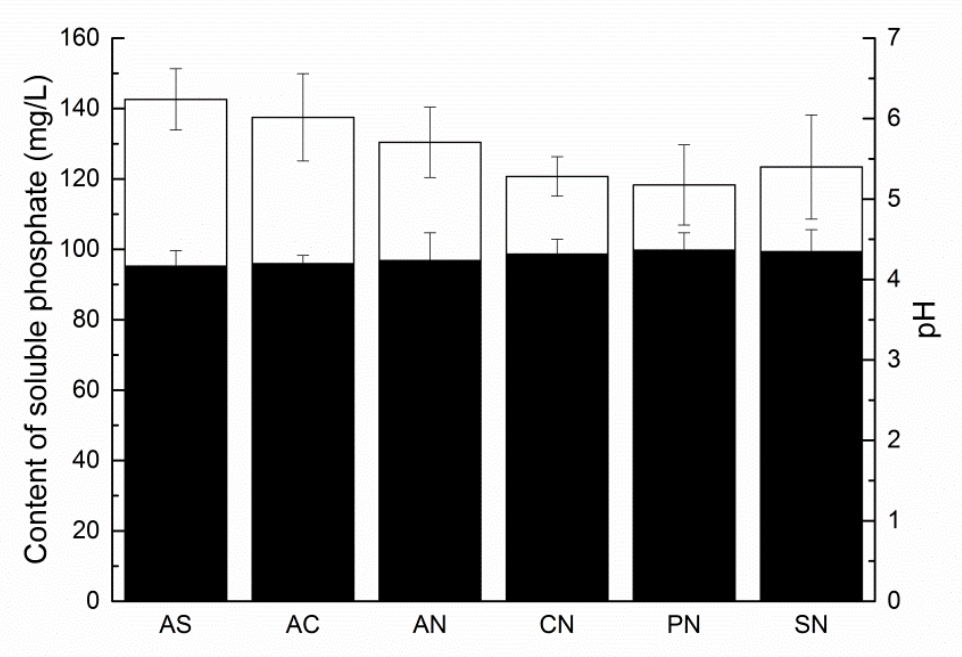

Figure 5- Effect of ammonium and nitrate nitrogen sources on RP solubilization by A. japonicus after 7 days inoculation. Results represent the mean of three replicates \pm standard deviation.

\section{DISCUSSION}

Biotechnology seems to be an attractive approach in the scientific utilization of lowgrade RP resource that has been actively studied during the last decade ${ }^{22}$. Use of phosphate-solubilizing microorganisms as bioinoculants will increase the available phosphorus in soil, helps to minimize the phosphate fertilizer application, reduces environmental pollution and promotes sustainable agriculture. The results in this study indicated that $A$. japonicus could effectively solubilize RP in NBRIP medium, and thus this fungus may have a better potential to serve as an agent to convert insoluble RP into soluble forms.

Tricalcium phosphate is the main component of RP. The solubilization of PR in acidic condition can be described by the following equation:

$\mathrm{Ca}_{3}\left(\mathrm{PO}_{4}\right)_{2}+4 \mathrm{H}^{+} \leftrightarrow 3 \mathrm{Ca}^{2+}+2 \mathrm{PO}_{4}{ }^{3-}+4 \mathrm{H}^{+} \leftrightarrow 3 \mathrm{Ca}^{2+}+2 \mathrm{HPO}_{4}{ }^{2-}$

$+2 \mathrm{H}^{+} \leftrightarrow 3 \mathrm{Ca}^{2+}+2 \mathrm{H}_{2} \mathrm{PO}_{4}^{-}$(1) 
Rock phosphate solubilization by A. japonicus

According to the equation (1), the solubilization of PR may be enhanced by the supply of protons and/or the removal of solubilization products, in particular calcium cations and phosphorus cations. It was concluded from the present study that $A$. japonicus could excrete multiple organic acids, and followed by an increase of quantity of titratable acidity and a decrease of $\mathrm{pH}$ in the culture. It reaffirmed that the phosphate solubilization by microorganisms was involved with the production of organic acids ${ }^{18}$. The obverse relationship observed between soluble phosphate content and quantity of titratable acidity and the inverse relationship observed between soluble phosphate content and $\mathrm{pH}$ indicated that the production of organic acids by A. japonicus played a significant role in the RP solubilization. However, there were also studies showed that no significant relationship could be established between the content of soluble phosphate released, titratable acidity, and $\mathrm{pH}^{2,5,9}$.

Production of organic acids was an important mechanism, but was not the only possibility for the biosolubilization of RP. The release of protons accompanying respiration or $\mathrm{NH}_{4}^{+}$assimilation was also a mechanism of RP solubilization by $A$. japonicus. However, the hypothesis that phosphate solubilization is linked to acidification caused by $\mathrm{NH}_{4}^{+}$assimilation does not hold true for all microorganisms ${ }^{23,24}$.

Phosphate-solubilizing microorganisms are known to produce phosphatases, which are hydrolytic enzymes, responsible for the breakdown of insoluble phosphates ${ }^{25}$. However, it just detected trace phosphatases in the broth in the present study. Phosphatases may be more involved in the soil for phosphate solubilization ${ }^{6}$. It was not clear of the mechanisms of RP solubilization by microorganisms. RP solubilization is not a simple phenomenon and may be determined by many factors, such as the nature of RP and its concentration, different microorganisms and so on. Therefore, it needs further studies to understand the mechanisms of RP solubilization used by different microorganisms in different RP resources.

\section{CONCLUSIONS}

An isolated strain, namely A. japonicus, can effectively solubilize RP and release soluble phosphate in NBRIP medium. The main mechanism of RP solubilization is the production of organic acids (principally gluconic acid), which played a vital role in the acidification of the broth, followed by the decrease in $\mathrm{pH}$, and thus further facilitated the solubilization of RP. Another mechanism is that cells of A. japonicus attached rapidly to RP surface, and thus the RP surface was seriously corroded by the strain. An abiotic study using organic or inorganic acid to solubilize RP indicated that the content of soluble phosphate released was significantly lower than was detected in the broth inoculated with the isolates. The enhancement of the release of soluble phosphate and $\mathrm{pH}$ reduction was observed when ammonium rather than nitrate acts as the sole source of nitrogen with RP in NBRIP medium.

\section{ACKNOWLEDGEMENTS}

The authors acknowledge the financial support of National Natural Science Foundation of China (51674178) and the program for Excellent Young Scientific and Technological Innovation Team of Hubei Provincial Department of Education, China (T201506). 


\section{REFERENCES}

1- Hilda R, Fraga R. Phosphate solubilizing bacteria and their role in plant growth promotion. Biotechnol Adv. 1999; 77: 319-359.

2- Reddy M S, Kumar S, Babita K, Reddy M S. Biosolubilization of poorly soluble rock phosphates by Aspergillus tubingensis and Aspergillus niger. Bioresour Technol. 2002; 84: $187-189$.

3- Rajan S S, Watkinson J H, Sinclair A G. Phosphate rocks for direct application to soil. Adv Agron. 1996; 57: 77-159.

4- Behera B C, Singdevsachan S K, Mishra R R, Dutta S K, Thatoi H N. Diversity, mechanism and biotechnology of phosphate solubilising microorganism in mangrove $-\mathrm{A}$ review. Biocatal Agric Biotechnol. 2014; 3: 97-110.

5- Chen Y P, Rekha P D, Arun A B, Shen F T, Lai W A, Young C C. Phosphate solubilizing bacteria from subtropical soil and their tricalcium phosphate solubilizing abilities. Appl Soil Ecol. 2006; 34: 33-41.

6- Achala V, Savantb V V, Reddy M S, Phosphate solubilization by a wild type strain and UV-induced mutants of Aspergillus tubingensis. Soil Biol Biochem. 2007; 39: 695-699.

7- Selvakumar G, Joshi P, Suyal P, Mishra P K, Joshi G K, Venugopalan R, Bisht J K, Bhatt J C, Gupta H S. Rock phosphate solubilization by psychrotolerant Pseudomonas spp. and their effect on lentil growth and nutrient uptake under polyhouse conditions. Ann Microbiol. 2013; 63: 1353-1362.

8- Vassilev N, Vassileva M, Azcon R. Solubilization of rock phosphate by immobilized Aspergillus niger. Bioresour Technol. 1997; 59: 1-4.

9- Narsian V, Patel H H. Aspergillus aculeatus as a rock phosphate solubilizer. Soil Biol Biochem. 2000; 32: 559-565.

10- Nautiyal C S. An efficient microbiological growth medium for screening phosphatesolubilizing microorganisms. FEMS Microbiol Lett. 1999; 170: 265-270.

11- Jiang L H, Zhao S L, Zhu J H. Fast destination of $\mathrm{P}_{2} \mathrm{O}_{5}$ in melamine phosphate. Chem Eng. 2001; 85: 50-51.

12- Yi Y M, Huang W Y, Ge Y. Exopolysaccharide: a novel important factor in the microbial dissolution of tricalcium phosphate. World J Microbiol Biotechnol. 2008; 24: 1059-1065.

13- Xiao C Q, Chi R A, He H, Qiu G Z, Wang D Z, Zhang W X. Appl Biochem Biotechnol. 2009; 159: 330-342.

14- Tahatabai M A, Bremner J M. Use of $\rho$-nitrophenyl phosphate for assay of soil phosphatase activity. Soil Biol Biochem. 1969; 1: 301-307.

15- Halder A K, Mishra A K, Bhattacharya P, Chakrabarthy P K. Solubilization of rock phosphate by Rhizobium and Bradyrhizobium. J Gen Appl Microbiol. 1990; 36: 81-92.

16- Goldstein A H. Recent progress in understanding the molecular genetics and biochemistry of calcium phosphate solubilization by Gram negative bacteria. Biol Agric Hort. 1995; 12: 185-193.

17- Rashid M, Khalil S, Ayub N, Alam S, Latif F. Organic acids production and phosphate solubilization by phosphate solubilizing microorganisms (PSM) under in vitro conditions. Pak J Biol Sci. 2004; 7: 187-196.

18- Kpomblekou K, Tabatabai M A. Effect of organic acids on release of phosphorus from phosphate rocks. Soil Sci. 1994; 158: 442-453.

19- Tributsch H. Direct versus indirect bioleaching. Hydrometallurgy. 2001; 59: 177-185.

20- Illmer P, Schinner F. Solubilization of inorganic calcium phosphates- solubilization mechanisms. Soil Biol Biochem. 1995; 27: 257-263.

21- Parks E J, Olson G J, Brinckman F E, Baldi F. Characterization by high performance liquid chromatography (HPLC) of the solubilization of phosphorus in iron ore by a fungus. J Ind Microbiol. 1990; 5: 183-190.

22- Whitelaw M A. Growth promotion of plants inoculated with phosphate solubilizing fungi. Adv Agron. 2000; 69: 99-151.

23- Chuang C C, Kuo Y, Chao C C, Chao W L. Solubilization of inorganic phosphates and plant growth promotion by Aspergillus niger. Biol Fertil Soils. 2007; 43: 575-584.

24- Reyes I, Bernier L, Simard R R, Antoun H. Effect of nitrogen source on the solubilization of different inorganic phosphates by an isolate of Penicillium rugulosum and two UVinduced mutants. FEMS Microbiol Ecol. 1999; 28: 281-290. 
Rock phosphate solubilization by A. japonicus

25- Rinu K, Pandey A. Slow and steady phosphate solubilization by a psychrotolerant strain of Paecilomyces hepiali (MTCC 9621). World J Microbiol Biotechnol. 2011; 27: 10551062.

Received: February 03, 2016; Accepted: July 14, 2016 


\section{Erratum}

In Article "Characteristics and Mechanisms of Biosolubilization of Rock Phosphate by Aspergillus japonicus", with DOI number: http://dx.doi.org/10.1590/1678-4324-2017160541, publish in journal Brazilian Archives of Biology and Technology, vol. 60, the page 1.

That read:

“http://dx.doi.org/10.190/1678-4324-2017160541"

Read:

“http://dx.doi.org/10.1590/1678-4324-2017160541" 